\title{
FAMILIA ÎN ERA DIGITALĂ (I)
}

\author{
Pr. prof. univ. dr. Ioan C. TEȘU \\ Facultatea de Teologie Ortodoxă „Dumitru Stăniloae” din Iași \\ https://doi.org/10.47433/tv.xcvin5-8.5
}

\begin{abstract}
Digital technology is, undoubtedly, part of the contemporary human's life. It has not only trickled into our professional activities, but it has also invaded our family, our relationships, and our own true soul. The "digital natives" generation is born and rises alongside it. For these youngsters, technology is not an instrument, but a confidant and a friend. However, the effects it implies due to abusive usage are unfortunately affecting, in particular, younger ages than ever before. In the first part of the study, the author emphasizes the impact of the technological devices on the process of diminishing the quality of connection between spouses, on one hand, and between parents and their children, on the other. Numerous statistics regarding the amount of time spent in front of the PC, laptop or smartphone are presented, this period of time adding up to roughly 11 years of life. The outlook is one of morality. Without dispraising technology, the author advices his readers on approaching a more purposeful manner of digital usage, thus promoting the cultivation of attitudes and activities which lead to a better understanding of the importance of empathy, compassion and emotional resilience. In support of his ideas come the examples of quality time spend with own family, creating meaningful connections with other people and spending time finding oneself in nature.
\end{abstract}

Keywords: Digital technology, „Net Generation”, spiritual life, digital addiction, discernment.

\section{Vocaţia ființei umane - iubire şi mântuire}

O privire morală asupra lumii și a vremurilor în care trăim va descoperi o slăbire a duhului de apropiere și comuniune dintre oameni. Cultura egoismului și a individualismului, preocuparea pentru binele personal și al unui grup restrâns de apropiați duc la slăbirea relațiilor autentice dintre oameni, la „dezînsuflețirea" sau „devitalizarea” lor. Aceasta are, în mod negreșit, efecte puternice asupra ființei umane, care a fost creată pentru comuniune și nu spre a trăi în însingurare. 
Unul dintre cei mai importanți predictori ai sănătății fizice și spirituale îl constituie numărul și calitatea relațiilor sociale de care dispune o persoană, adică prietenii săi apropiați, începând cu membrii familiei. Singurătatea chiar doare. Ea nu este doar o stare de lipsă sufletească sau de gol interior, ci afectează fizic aceiași centri cerebrali, ca și durerea fizică, fiind resimțită atât la nivel sufletesc, dar și fizic ${ }^{1}$.

Studiile privind originea și vocația ființei umane evidențiază importanța unor relații sociale fericite, pentru starea de împlinire a ei. Cei mai valoroși terapeuți de familie au demonstrat că bărbații căsătoriți își lungesc viața cu opt ani (cam tot atât cât face o atitudine optimistă de viață), iar femeile, în cazul în care sunt împlinite, cu patru ani ${ }^{2}$.

Bucuria prietenilor adevărați devine și bucuria noastră. Un studiu laborios a arătat că atunci când prietenii locuiesc într-un perimetru de 2 km, bucuria unuia dintre ei, împărtășită celuilalt, îi îmbunătățește celui din urmă starea de bine sufletesc, în proporție de $25 \%$. Dacă acesta transmite mai departe, unui alt prieten comun, bucuria celui dintâi, îi adaugă acestuia cu 10\% mai multă împlinire. Dacă și acesta o transmite unui al treilea, îi adaugă 5,6\% fericire. Or, pentru ca o persoană să-și adauge fericirii sale $2 \%$, îi trebuie 5.000 de dolari. Alți cercetători au calculat ce sumă de bani ar putea acoperi lipsa oricărui prieten și s-a constatat că aceasta ar trebuie să fie de minim 6.000 de euro pe lună ${ }^{3}$. Bani cu ajutorul cărora, probabil, persoana lipsită de afecțiunea prietenilor și de căldura prieteniilor să-și anestezieze durerea și să-și păcălească, prin distracții variate, conștiința. Numai că, în momentul în care se trezește din mirajul și dulceața efemeră a acestora, realizează, din nou, starea în care se află, precum și neputința tuturor mijloacelor de loisir și distracție de a-i umple existența și a-i da sens înalt vieții.

\footnotetext{
${ }^{1}$ John T. Cacioppo, William Patrick, Singurătate. Natura umană şi nevoia de conexiune umană, traducere din limba engleză de Radu Şorop, Editura Vellant, Bucureşti, 2018, p. 24.

${ }^{2}$ Dr. John Gottman, Dr. Julie Schwartz Gottman, Douglas Abrams, Dr. Rachel Carlton Abrams, Totul despre femei. Ghid pentru bărbați, Editura Niculescu, București, 2017, p. 218.

${ }^{3}$ Jordi Quoidbach, De ce trăiesc mai mult oamenii fericiți, traducere, adaptare, redactare, corectură: Daniel Voinea, House of Guides Publishing Group, s.l. p. 2011, p. 31 .
} 
Și astfel cade, din nou, în plasa și în robia lor. Dureri mai mari cer plăceri sporite, iar acestea conduc la suferințe și mai intense. Și tot așa, din durere în durere, prin intermediul plăcerilor trecătoare, din cădere în cădere, cu scurte momente de ridicare, spre epuizarea puterilor lui fizice și sufletești. Într-adevăr, un prieten bun prețuiește mai mult decât aurul sau, precum spune proverbul: „Avem atât de puțini prieteni buni, încât nu ne permitem luxul să pierdem vreo unul".

Sfântul Ioan Gură de Aur († 407) considera că un prieten adevărat este un „,al doilea eu”, alături de care putem înfrunta arșița și gerul, exilul și străinătatea. În lipsa unul astfel de prieten bun, nici țara nu ni-i țară, nici casa nu ni-i casă, nici viața nu ni-i viață. Sau cum atât de frumos o spunea Sfântul Părinte: „Prietenul adevărat este mai plăcut decât chiar viața prezentă, căci mulți după încetarea din viață a unor asemenea prieteni, nu mai doresc să trăiască. Cu un asemenea prieten, cineva poate suferi și exilul, iar fără prieteni nu poate trăi nici în propria sa țară. Cu un asemenea prieten chiar și sărăcia este suportabilă, iar fără dânsul și sănătatea și bogăția sunt de nesuferit. În persoana unui asemenea prieten el are un al doilea eu" ${ }^{\prime \prime}$.

Existența unor prieteni de suflet, apropiați și atașați, ne sporește și ne îmbogățește bucuriile vieții, printre numeroasele necazuri de care avem parte, după cum lipsa lor ne face singurătatea și mai apăsătoare.

Omul nu a fost creat pentru singurătate, ci pentru comuniune, prin primire și dăruire de iubire. El simte permanent nevoia de a-și afla un suflet confident și drag, cu care să împărtășească bucuriile și încercările vieții prezente. Căci, alături de un astfel de suflet, „,bucuriile se dublează, iar necazurile se înjumătățesc”. Simte nevoia de a găsi un umăr pe care să iși plece fruntea obosită și îngândurată, spre căutarea păcii lăuntrice pierdute, o mână care să îl strângă și să îl sprijine în momentele grele, un braț care să îl cuprindă și să îl susțină, atunci când nu mai are sprijin.

\footnotetext{
${ }^{4}$ Sfântul Ioan Gură De Aur, „CComentariile sau Explicarea Epistolei I către Tesaloniceni. Omilia II", în vol. Comentariile sau Explicarea Epistolei către Coloseni, I și II Tesaloniceni a Sfântului Apostol Pavel, traducere din limba elină, ediția de Oxonia, 1855, de Arhim. Theodosie Athanasiu, București, 1905, p. 181, în „Lumina Sfintelor Scripturi (Antologie tematică din opera Sfântului Ioan Gură de Aur), antologie și studii introductive", drd. Liviu Petcu, Editura Trinitas, Iași, 2007, p. 686.
} 
Lumea în care trăim ne oferă numeroase oportunități pentru legarea și dezvoltarea relațiilor interumane, chiar a prieteniilor și relațiilor de prietenie și afecțiune. Oriunde ne-am afla, avem numeroase mijloace prin care să comunicăm cu ei, iar comunicarea, ca revelare a celuilalt și ca autodescoperire de sine, este o cale spre comuniune și fuziune spirituală.

Nu putem iubi cu adevărat decât ceea ce cunoaștem profund și nu putem cunoaște deplin decât ceea ce iubim real, înalt și curat. Cunoașterea și iubirea se întrețin și se dezvoltă una pe alta. Un anume fel de cunoaștere a ceea ce este frumos și bun în viața cuiva, ni-l apropie sufletește. La fel, iubirea sinceră ne ajută să-l cunoaștem și să pătrundem tot mai adânc și profund în universul de taine pe care îl reprezintă viața și sufletul celuilalt. Iubirea angajează cunoașterea; cunoașterea sporește iubirea.

Iar dintre persoanele apropiate, familia ni le oferă pe cele mai dragi. Totul începe și se încheie în familie, pentru că ea ne oferă bucuriile cele mai frumoase, mai înalte și mai curate. Neîmplinirea în viața de familie nu este doar o „,scădere” particular, ci înseamnă însăși prăbușirea persoanei, ca vocație și sens. În momentul în care se pierd aceste valori ale familiei, nu se distruge doar o căsnicie, ci se subminează ființa unui neam. Când familiile sunt stabile, statornice și puternice, neamul întreg are de profitat. Când, însă, valorile ei sunt relativizate, ignorate, încălcate, pervertite, nu este afectată doar familia, ci însuși neamul din care ea face parte. Antropologul britanic John D. Urwin a făcut un studiu aprofundat asupra a optzeci de civilizaţii care au dispărut de-a lungul a 4000 de ani. El a descoperit că, în evoluția acestui proces, există un punct comun. De fiecare dată, s-a început cu un set de valori morale conservatoare, punându-se accent asupra familiei. După un timp, aceste principii au devenit tot mai laxe, valorile morale au dispărut şi familia a avut de suferit. În toate cazurile, pe măsură ce familia s-a deteriorat, civilizaţia căreia se subscria a început să se destrame; în toate aceste optzeci de cazuri, prăbuşirea unui popor a avut o strânsă legătură cu destrămarea familiei. În majoritatea cazurilor, civilizaţia a dispărut după o generație, în raport cu dispariţia fami$\operatorname{liei}^{5}$. Din acest motiv, familia și valorile ei morale trebuie păstrate

${ }^{5}$ Zig Zilgar, Secretul căsniciei fericite. Idila poate dura o viaţă, Ediția a II-a, traducere din engleză de Irina-Margareta Nistor, Curtea Veche, Bucureşti, 2017, p. 20. 
ca un adevărat bastion de rezistență în fața tuturor încercărilor, ispitelor și frământărilor.

\section{Intruziunea tehnologiei digitale în viaţa omului contemporan}

Jean-Claude Larchet, referindu-se la pătrunderea tehnologiei în viața omului contemporan, afirma: „Nici o altă tehnologie nu s-a infiltrat în activitatea noastră zilnică pentru un timp atât de îndelungat, nu a solicitat atenția şi intervenţia noastră atât de constant, nu a invadat atât de mult viața noastră privată, familială şi privată, nu a pătruns atât de profund în lăuntrul vieții noastre sufleteşti. Nici o altă tehnologie nu a transformat atât de mult raporturile noastre cu spaţiul şi timpul, felul nostru de a vedea lumea, relaţiile noastre cu ceilalți, reprezentarea pe care o avem despre noi, natura şi ritmul activităţilor noastre de la serviciu şi din timpul liber, forma noastră de comunicare, ca şi natura, structura şi forma vieţii noastre psihice şi intelectuale. Şi nici o altă tehnică, prin influenţa exercitată asupra modului nostru de a fi, care constituie textura existenței noastre, nu a avut un impact atât de important asupra vieții noastre spirituale" ${ }^{\prime \prime}$.

Iar Nicholas Carr, observând efectele lumii virtuale asupra propriului suflet, constata stupefiat: „In ultimii ani, am avut senzația neplăcută că cineva, sau ceva, a meşterit prin creierul meu, reconfigurând circuitele neuronale şi reprogramând memoria. Mintea mea nu e pe ducă - pe cât se poate -, dar se modifică. Nu mai gândesc aşa cum obişnuiam să o fac. O simt cel mai tare atunci când citesc. Eram obişnuit să-mi pară uşor să mă scufund într-o carte sau într-un articol lung. Mintea mea era prinsă în urzeala narativă sau în meandrele argumentării şi-mi petreceam ore în şir cutreierând agale prin lungi fragmente de proză. Rar mi se întâmplă. Acum concentrarea mea începe să o ia razna după o pagină sau două. Devin agitat, pierd şirul, încep să caut altceva de făcut. Mereu am senzaţia că-mi târâi creierul îndărătnic, forțându-1 să revină la text. Lectura profundă, care obişnuia să vină firesc, a devenit un efort" ${ }^{\prime 7}$.

${ }^{6}$ Jean-Claude Larchet, Captivi în internet, în româneşte de Marinela Bojin, Editura Sophia, Bucureşti, 2018, pp. 5-6.

${ }^{7}$ Nicholas Carr, Superficialii. Efectele internetului asupra creierului uman, traducere din engleză de Dan Crăciun, Editura Publica, Bucureşti, 2012, p. 23. 
Încercând să identifice cauzele acestei transformări din mintea și din viața sa, același autor constata: „Cândva, prin 2007, un şarpe de îndoială s-a strecurat târâş în info-paradisul meu. Am început să bag de seamă că netul exercita asupra mea o influență mult mai puternică şi mai vastă decât o făcuse vreodată vechiul meu PC solitar. Nu era doar faptul că stăteam atât de mult holbându-mă la un monitor. Nu era doar faptul că atât de multe dintre obiceiurile şi rutinele mele se schimbau pe măsură ce deveneam tot mai deprins cu şi tot mai dependent de site-urile şi serviciile de pe net. Chiar felul în care funcţiona creierul meu păreau să se schimbe. Atunci a început să mă preocupe incapacitatea mea de a da atenţie unui lucru mai mult de câteva minute. La început, am socotit că problema era un simptom de atrofiere a minții la vârsta mijlocie. Însă creierul meu, mi-am dat seama, nu doar o lua razna. Era flămând. Cerea să fie hrănit aşa cum îl hrănea netul - şi cu cât înghiţea mai multă hrană, cu atât foamea sporea. Chiar şi atunci când nu eram lângă computer, tânjeam să-mi verific mailul, să clichez pe linkuri, să fac ceva Googling. Voiam să fiu conectat. Aşa cum Microsoft Word mă transformase într-un procesor de cuvinte în carne şi oase, internetul, am simţit, mă transforma în ceva asemănător cu o maşină de procesare a datelor de mare viteză, un HAL uman. Mi s-a făcut dor de vechiul meu creier" ${ }^{8}$.

În lipsa unei stări de trezvie, adică de pază atât față de provocările exterioare, cât și de trăirile noastre lăuntrice, vulnerabilitatea față de atracția tehnologiei digitale este lângă noi, la un click distanță.

În privința timpului petrecut în fața televizorului, același JeanClaude Larchet constata că europenii petrec zilnic, în medie, în fața ecranului, 3 ore și 48 de minute 9 . Preferințele generației mature pentru televiziune au fost înlocuite, la cei mai tineri, de atracția față de internet, la care au acces de pe diferite dispozitive (PC, tabletă, laptop, telefon inteligent etc). Acestea sunt mult mai accesibile și mai confortabile, oferind opțiuni nenumărate de petrecere a timpului. Dacă urmărirea unui program TV implica întrunirea întregii familii, de obicei în sufragerie sau living, și urmărirea în comun a aceluiași program, mai nou, trei sau patru membri ai acesteia se

\footnotetext{
${ }^{8}$ Ibidem, pp. 36-37.

${ }^{9}$ J.-C. Larchet, Captivi în internet..., p. 13.
} 
pot afla în camere diferite, fiecare în fața device-ului personal și urmărind programul său favorit. Ba chiar nici nu mai trebuie așteptat, ca în cazul cinematografului de altădată - apariția și distribuirea unui film - nici ca în cazul televiziunii - difuzarea, la anumite intervale de timp, a episoadelor unui serial. Acum se pot urmări, zilnic, atât cât îți permite timpul - mai multe episoade, iar în câteva zile - sezoane întregi. Dacă în compania televizorului se petrec aproximativ 4 ore zilnic, atunci când este vorba despre consumul de internet, acesta variază între 6 și 9 ore pe zi, cei mai mari consumatori de media fiind adolescenții.

\section{Caracterul cronofag al tehnologiei digitale}

La modul general, $12 \%$ dintre utilizatorii tehnologiei digitale petrec în fața ecranelor între $0-1$ oră; $22 \%$, între $1-2$ ore; $25 \%$, între $2-3$ ore; $18 \%$, între 3 și 4 ore; $12 \%$, aproximativ $4-5$ ore; $7 \%$, între 5-6 ore; $3 \%, 6-7$ ore, iar un procent de $1 \%$, la care se constată de obicei dependență față de tehnologia digitală, peste 7 ore $^{10}$. Aceasta înseamnă că omul contemporan „petrece un sfert din starea de veghe cu telefonul în mână - mai mult timp decât investeau în orice altă activitate cotidiană, cu excepția somnului. În fiecare lună, se adună aproape o sută de ore pierdute cu verificarea e-mailului, scrierea de mesaje, jocuri, navigare pe internet, articole citite, verificări de solduri bancare etc. Raportate la speranța de medie de viață, acestea se cumulează într-o cantitate de timp uluitoare-unsprezece ani din viață. De asemenea, utilizatorii iau telefoanele în mână, în medie, de trei ori în fiecare oră. Această categorie de folosire excesivă are o incidență atât de mare încât cercetătorii au consacrat termenul de «nomofobie», pentru a descrie teama de a nu fi în contact cu telefonul mobil (o abreviere pentru «no-mobile-phobia»)"11.

Lucrurile devin și mai grave, atunci când este vorba despre copii. Potrivit Declarației oficiale a Academiei Americane de Pediatrie, publicată în anul 2013, dar care ar trebui revizuită, negativ, din cauza acestor comportamente digitale, „copiii cu vârste cuprinse între 8 și 10 ani petrec aproape 8 ore pe zi cu dispozitivele

${ }^{10}$ Adam Alter, Irezistibil. Dependenţa de tehnologie şi afacerile din spatele ei, traducere din engleză de Emilia Vasiliu, Editura Publica, Bucureşti, 2017, p. 26.

${ }^{11}$ Ibidem, p. 27. 
media. Copiii mai mari și adolescenții petrec mai mult de 11 ore pe zi cu dispozitivele media. $71 \%$ dintre copii au televizor sau conexiune la internet în camera lor. 3 din 4 tineri, cu vârste cuprinse între 12 și 17 ani, au telefon mobil. 1 din 3 adolescenți trimite mai mult de 100 de mesaje pe zi (acestea înlocuind în mare măsură apelurile telefonice). Copiii noștri petrec mai mult timp cu dispozitivele media decât la școală, timp depășit doar de cel rezervat somnului. 2 din 3 copii și adolescenți declară că părinții lor nu au reguli pentru folosirea dispozitivelor media" ${ }^{\prime 2}$. Iar în privința modului în care tinerii petrec acest timp, același for medical a constatat că 25\% dintre aceștia stau pe rețelele de socializare; 19\% accesează jocuri video; $6 \%$ stau pe site-uri video; $12 \%$ stau pe alte site-uri; $13 \%$ dintre ei citesc mesaje; $6 \%$ își verifică e-mailurile; $5 \%$ privesc diverse ilustrații sau fotografii, iar 5\% desfășoară alte activități în spațiul virtual ${ }^{13}$.

Elevii de școală primară, indiferent că sunt băieți sau fete, petrec, din cele două ore pe zi, consacrate mijloacelor digitale, aproape 70 de minute în fața televizorului (online, pe DVD sau alt format), 30 de minute explorând lumea jocurilor digitale și aproximativ 25 de minute citind cărți sau benzi desenate, singuri sau cu ajutorul părinților ${ }^{14}$.

Adolescenții sunt cei mai consecvenți consumatori de tehnologie. Ea face parte din viața lor, de când se nasc, și le umple ziua, din clipa în care se trezesc și până se culcă, noaptea, târziu. Ei petrec în jur de șase ore pe zi în compania mass-media. Din acest total, două ore le petrec comunicând cu prietenii și colegii, pe diverse rețele, iar mai bine de oră pe zi sunt prezenți pe rețelele de socializare ${ }^{15}$. Pe măsură ce se realizează trecerea de la copilărie la adolescență, cantitatea de timp petrecut în spațiul virtual crește, progresiv, ajungând la șase ore pe zi, ba chiar la nouă ore, iar în cazuri extreme, la douăsprezece ore zilnic.

${ }^{12}$ Dr. Martin L. Kutscher, Copiii erei digitale. Cum să limităm timpul petrecut în fața ecranului și de ce este important acest lucru, traducere de Cătălin-Mihai Ștefan, Editura Univers, București, 2018, pp. 10-11.

${ }^{13}$ Ibidem, pp. 11-12.

${ }^{14}$ Patti M. Valkenburg, Jessica Taylor Piotrowski, Generaţia digitală şi dependența de media, traducere: Luiza Mohonea, Editura Niculescu, Bucureşti, 2018, p. 75.

${ }^{15}$ Ibidem, p. 89. 
Aceeași Academie Americană de Pediatrie arată că 62\% dintre elevii (adolescenți) din „,Generația Z" sau „iGeneration” ${ }^{16}$ afirmă că-și verifică aparatele digitale cel puțin o dată la 15 minute; adolescenții au primit și au trimis 3705 mesaje pe lună, cam 6 pe oră ${ }^{17}$.

Atunci când vine vorba despre atât de popularul telefonul inteligent sau smartphone, cercetările arată că utilizatorii lui îl verifică, în medie, de 27 de ori pe zi, adică între 14 și 140 de ori pe zi, de cele mai multe ori fără nici motiv. $42 \%$ dintre adulți și 55\% dintre tineri își verifică telefonul ori de câte ori au timp, iar $23 \%$ susțin că fac acest lucru când nu au ceva anume de făcut ${ }^{18}$. In privința mediilor sau a locurilor unde îl utilizează, s-a observat că 55\% dintre adulți își verifică telefonul atunci când conduc, 35\% își verifică telefonul la spectacole sau filme, în ciuda avertizărilor primite înaintea începerii filmului, 33\% îl folosesc la masă sau cină, atunci când se află în prezența familiei, a prietenilor sau colegilor; $32 \%$ dintre părinți îl folosesc chiar și atunci când sunt prezenți la un eveniment școlar al copilului; 19\% accesează telefonul la biserică, $12 \%$ la duș, iar $9 \%$ îl folosesc în timpul relațiilor intime ${ }^{19}$. Tot astfel, 3 din 4 utilizatori de smartphone admit că stau la câțiva metri de telefon noaptea, iar 75\% dintre tineri și adolescenți dorm cu el lângă pat. Aproape opt din zece utilizatori de telefon mobil se întind după el la maximum un sfert de oră după ce se trezesc, iar pentru $62 \%$, telefonul este primul lucru pe care îl caută, imediat ce deschid ochii ${ }^{20}$.

\section{Efectele ecranelor digitale asupra copiilor}

Experții în studierea efectelor tehnologiei digitale asupra copiilor au constatat că, în ciuda avertismentelor forurilor medicale internaționale competente, producătorii, în mod deliberat, realizează

\footnotetext{
${ }^{16}$ Sub denumirea de "generația Z", ,post-milenialii”, ,,iGeneration”, , ,generația net", ,generația Tech" sau „nativii digitali” sunt socotiți cei născuți între 1995-2010.

${ }^{17}$ Dr. M.L. Kutscher, Copiii erei digitale..., p. 62.

${ }^{18}$ Adam Gazzaley, Larry D. Rosen, Mintea distrată. Creiere vechi într-o lume puternic tehnologizată, traducere din engleză de Ruxandra Vișan, Editura Trei, București, 2019, pp. 167-168.

${ }^{19}$ Ibidem, p. 168.

${ }^{20}$ Ibidem, pp. $168-169$.
} 
programe pentru categoriile vulnerabile, precum copiii și adolescenții, introducând în ele elemente ce pot crea dependență. $\mathrm{O}$ asemenea categorie o constituie nou-născuții și copiii până la 2 ani. Se vorbește, astfel, despre „publicul în scutece” ${ }^{21}$, despre „digiprichindei" ${ }^{\prime 22}$ și „,tehno-puști" ${ }^{23}$, categorii aflate în atenția producătorilor de tehnologie. Copiii, de la vârste fragede, sunt expuși, indirect, la diversele dispozitive digitale, care devin ",bone electronice”, pentru ca părinții lor să poată desfășura alte activități curente, casnice sau profesionale.

Constatând că micuții sub doi ani sunt expuși, zilnic, timp de aproape șase ore, la programe de televiziune, derulate pe fundal, aceeași Academie Americană de Pediatrie a avertizat părinții să interzică orice fel de acces al copiilor sub vârsta de doi ani, la orice fel de mijloc mass-media ${ }^{24}$, și înlocuirea ei cu practicarea unor activități benefice pentru dezvoltarea lor fizică și mintală: dialogul cu părinții, cu membrii familiei, rude etc. jocul imaginativ, plimbările în aer liber, lectura de povești, adaptate nivelului lor aperceptiv. Efectul avertismentelor nu a fost, însă, cel dorit, constatându-se că, în prezent, copiii sub 2 ani se uită la televizor 1-2 ore pe zi, pe lângă alte 4 ore, în care televizorul este lăsat deschis de părinți, fie că sunt atenți sau nu la programele derulate ${ }^{25}$.

În spatele acestor recomandări medicale se află zeci de ani de cercetare științifică, unele dintre ele efectuate cu ajutorul aparaturii de rezonanță magnetică. În ceea ce îi privește pe copii, analiza și interpretarea imaginilor obținute au arătat că dezvoltarea cea mai intensă a creierului uman se petrece până în jurul vârstei de cinci ani, în mod deosebit până la vârsta de trei ani. Acesta crește de la aproximativ 340 de grame, la naștere, la aproximativ 993 de grame, la finalul primului an de viață, iar după 5 ani, greutatea creierului nu se mai modifică, însă, în baza neurogenezei și a neuroplasticității cerebrale, circuitele neurale se dezvoltă până la vârsta

${ }^{21}$ Nicolas Carr, Cuşca de sticlă. Automatizarea şi noi, traducere din engleză de Vasile Decu, Publica, Bucureşti, 2014, p. 268.

${ }^{22}$ Jodi Glod, Părinte în era digitală. Învață-ți copilul cum să folosească adecvat rețelele sociale și aparatele digitale, traducere din engleză de Anca Sevcenco. Cuvânt înainte de Tory Burch, Editura Trei, București, 2016, p. 168.

${ }^{23}$ Ibidem, p. 168.

${ }^{24}$ P.M. Valkenburg, J. Taylor Piotrowski, Generația digitală şi dependența de media..., p. 270.

${ }^{25}$ Dr. M.L. Kutscher, Copiii erei digitale..., p. 85. 
de 5 ani și apoi continuă să se reorganizeze întreaga viață ${ }^{26}$. Circuitele din zona frontală a creierului, care controlează atenția, au cel mai rapid ritm de dezvoltare până la vârsta de trei-șase ani și, din acest motiv, atenția lor și așa limitată în această etapă a vieții, nu trebuie expusă la stimuli multipli și obositori ${ }^{27}$.

Vorbind despre „Baby-televiziune” sau despre televiziune pe postul de „Baby-sitter”, psihiatrul german Manfred Spitzer arăta că industria TV are de câțiva ani un nou grup-țintă: copiii între 4 și 24 de luni $^{28}$. Ca urmare, peste $80 \%$ dintre copiii de 2 până la 3 ani învață să deschidă singuri televizorul, mai bine de jumătate dintre ei știu să schimbe, din telecomandă, programele, iar peste $40 \%$ dintre aceștia știu să pornească DVD-ul ${ }^{29}$.

O cercetare făcută pe 1.000 de copii sub 2 ani, în legătură cu efectele folosirii DVD-urilor educaționale, special create pentru a îmbogăți vocabularul lor, ,"nu a găsit vreun avantaj oferit de DVDrile pentru bebeluși care promiteau să le îmbunătățească limbajul, iar mulți dintre ei au avut, de fapt, diminuări temporare în dezvoltarea limbajului" ${ }^{30}$. Mult mai eficientă a fost comunicarea directă cu părinții și joaca alături de aceștia și de alți copii.

Un efect negativ asupra copiilor de vârstă mică, la care simțul critic și puterea de control sunt slab dezvoltate, îl au reclamele. Astfel, s-a constatat științific faptul că, până începe școala, un copil care a fost expus, moderat, programelor și reclamelor TV, cunoaște peste 200 de nume de mărci și produse. Și, ceea ce este și mai interesant este că aceștia, atunci când vor vedea produsele respective, mai ales alimentare, vor dori să le fie oferite, dezvoltând, adeseori, comportamente compulsive de consum, iar ca efect obezitate și boli asociate acesteia. Concluzia oamenilor de știință, în această privință, este: „,cine consumă pe termen lung produsele la care se face reclamă își modifică propriul sistem de recompense,

${ }^{26}$ J. Glod, Părinte în era digitală..., pp. 68-69.

${ }^{27}$ Gary Chapman, Arlene Pellicane, Creșterea copiilor în era tehnologiei. Copii sociabili într-o lume a ecranelor, traducere de Raluca Mirăuță, Editura Casa Cărții, Oradea, 2018, p. 139.

${ }^{28}$ Manfred Spitzer, Demența digitală. Cum ne tulbură mintea noile tehnologii, traducere din germană de Dana Verescu, Editura Humanitas, București, 2020, p. 120.

${ }^{29}$ Ibidem, p. 121.

${ }^{30}$ Dr. M.L. Kutscher, Copiii erei digitale..., p. 86. 
după cum arată cercetările neurologice, și are mereu nevoie să mănânce tot mai mult, pentru a obține același efect plăcut" ${ }^{\prime 31}$.

Aceeași reacție s-a observat și în privința copiilor care sunt expuși programelor ce prezintă acte de violență. Astfel, „,cine vede multă violență la televizor sau se dedică jocurilor violente pe calculator, va deveni mai violent în viața reală" ${ }^{\prime 32}$.

Tot în legătură cu deprinderea limbajului de către copiii de vârstă mică, este cunoscută cercetarea făcută de un grup de experți din California, care a studiat efectul ascultării unei limbi străine asupra copiilor. După câteva luni, studiul a arătat că prezentarea pe ecran nu avusese nici un efect pozitiv, ci, dimpotrivă, inhibase capacitatea lor de învățare și aceasta întrucât „,copiii încep să învețe sunetele limbii materne la un an și jumătate. Pentru asta, au nevoie de un stimul potrivit: trebuie să audă limba. Şi trebuie să-l vadă pe vorbitor, pentru a pune în legătura ceea ce aud cu ceea ce văd (gura, chipul care exprimă emoțiile, probabil și limbajul corporal și contextul). Văzul contribuie la analizarea a ceea ce se aude. Creierul lucrează, deci, în paralel. Când ceva se vede și se aude în același timp, la milisecundă, atunci cele două trebuie să fie legate, așa cel puțin conchide creierul unui copil" ${ }^{\prime 33}$. Prin urmare, cercetările arată că, într-adevăr, ecranele mediilor nu numai că nu contribuie deloc la învățare, în prima copilărie, dar pot chiar să inhibe grav capacitatea de învățare ${ }^{34}$.

Așadar, atunci când este vorba despre efectele mediilor digitale educaționale, acestea „rămân nedemonstrate, în ciuda titlurilor seducătoare puse programelor și mărturiilor. Chiar și studiile făcute pe copii de 2 ani care urmăresc programe educaționale de foarte bună calitate (...) au constatat fie lipsa efectelor, fie efecte negative. Se pare să oamenii în carne și oase, care sunt prezenți fizic și acordă atenție, sunt cei mai eficienți în a pune la lucru centrii de învățare ai copilului mic, mai ales dacă acesta a stabilit o legătură cu ei" ${ }^{35}$.

Prezența și utilizarea tehnologiei, chiar și a unui televizor, în fundal, „poate afecta dezvoltarea copiilor, prin reducerea timpului

\footnotetext{
${ }^{31}$ M. Spitzer, Demenţa digitală..., p. 117.

${ }^{32}$ Ibidem, p. 119.

${ }^{33}$ Ibidem, p. 125.

${ }^{34}$ Ibidem, pp. $127-128$.

${ }^{35}$ Dr. M.L. Kutscher, Copiii erei digitale..., p. 171.
} 
pe care îl rezervă părinții pentru a le vorbi, pentru a le citi și pentru a se juca cu ei, așa cum poate diminua și timpul rezervat pentru joacă și citit. Mai multe studii au asociat consumul intens de media cu întârzierile în vorbire, mai ales când copilul se uită singur la ecran"36.

Pe baza cercetărilor, s-a observat că vârsta la care programele educaționale de înaltă calitate au efect este cea de 3-5 ani. La acești copii, media educațională , ajută la îmbunătătirea limbajului, a abilităților de socializare și a pregătirii pentru școală, efecte care se pot menține până la adolescență" ${ }^{37}$.

O altă discuție este cea legată de folosirea calculatorului în grădiniță. Răspunsul ferm, în această privință, ne este oferit de Manfred Spitzer, care arată că această practică „poate duce la tulburări de atenție, iar mai târziu, la dislexie. La vârsta școlară, se observă tot mai mult izolarea socială, după cum arată studii americane și, între timp, și germane ${ }^{\prime \prime 38}$.

Tot astfel, copiii care erau expuși la „baby-TV” și „baby-DVD” prezentau întârzieri în dezvoltarea limbajului și învățaseră mai puține cuvinte. Însă, „dacă unul din părinți citea zilnic copilului, s-a constatat un efect pozitiv asupra dezvoltării limbajului. Iar povestirea zilnică a unui basm avea un efect pozitiv semnificativ, la fel ca ascultarea muzicii de câteva ori pe săptămână (cu durată egală cu cea a narării orale); efectul pozitiv al muzicii nu era însă statistic semnificativ.

Gradul de nocivitate al consumului de medii digitale poate fi dedus din faptul că efectul său negativ asupra dezvoltării limbajului este de două ori mai puternic decât efectul pozitiv al citirii zilnice. Mai clar: «baby-TV» și «baby-DVD» sunt dăunătoare pentru dezvoltarea mentală a copiilor mici" ${ }^{39}$.

În lumina acestor constatări științifice, putem înțelege recomandările Academiei Americane de Pediatrie de a feri copiii până la vârsta de 2 ani de expunerea la orice fel de tehnologie și introducerea lor, în acest univers virtual, atât de atrăgător, odată cu creșterea și maturizarea lor emoțională și intelectuală.

\footnotetext{
${ }^{36}$ Ibidem, p. 171.

${ }^{37}$ Ibidem, p. 171.

${ }^{38}$ M. Spitzer, Demența digitală..., p. 23.

${ }^{39}$ Ibidem, p. 128.
} 
Iar, pe de altă parte, toate aceste constatări științifice ne oferă prilejul să observăm, încă o dată, intuiția extraordinară pe care au avut-o și o au Sfinții Părinți ai Bisericii creștine, în această privință, unii dintre ei cu un mileniu și jumătate în urmă. Sfântul Ioan Gură de Aur, spre exemplu, vorbea despre sufletul copilului ca despre un diamant în formă pură. El îl mai asemăna cu o ceară fragedă, pe care se inscripționează sigiliul. Atunci când ceara este caldă, inscripționarea este ușoară. Când aceasta, însă, se întărește, sigiliul devine tot mai greu de marcat. Tot el compara sufletul copilului cu o cetate, ale cărei porți sunt simțurile. Această cetate, învăța Sfântul Ioan Gură de Aur, trebuie păzită și de pericolele din interior, adică de pornirile subconștiente sau inconștiente, dar și de primejdiile din afară, de ispitele externe. Cei care trebuie să facă acest lucru, considera scriitorul creștin, sunt părinții, care, din acest punct de vedere, se aseamănă, în demnitate, nu doar cu marii pedagogi, ci cu împărații. Educația însăși devine o $\operatorname{artă}^{40}$.

La fel, Sfântul Paisie Aghioritul (1924-1994) compara sufletul fraged al copilului cu o casetă goală, pe care părinții și educatorii inscripționează muzică: Dacă muzica a fost bine aleasă, fiind una religioasă, aceeași muzică va fi redată de aceste „,casete”. Dacă, dimpotrivă, am înregistrat pe ele muzică imorală, ,"casetele” nu pot reda muzică creștină, decât dacă sunt șterse și reinscripționate, proces care cere mult efort și multă răbdare. Sufletul copilului fiind ca o astfel de casetă, responsabilitatea părinților în a transmite copiilor cunoștințele și deprinderile cele mai frumoase și înalte este specială ${ }^{41}$.

\section{Izolarea şi însingurarea digitală}

Tehnologia tot mai performantă și care, potrivit Legii Moore, își dublează, exponențial, volumul, la fiecare 12 luni, ar trebui să ajute și să întărească cultivarea și aprofundarea relațiilor de prietenie și

\footnotetext{
${ }^{40}$ Vezi Maica Magdalena, Sfaturi pentru o educație ortodoxă a copiilor de azi - cu un Cuvânt despre educația copiilor al Sfântului Ioan Gură de Aur, Editura Deisis, Sibiu, 2000.

${ }^{41}$ Cuviosul Paisie Aghioritul, Cuvinte duhovnicești. I. Cu durere și dragoste pentru omul contemporan, traducere din limba greacă de Ieroschim. Ștefan Nuțescu, Schitul Lacu - Sfântul Munte Athos, Editura Evanghelismos, București, 2003, p. 272.
} 
iubire, de empatie și compasiune dintre oameni. Dar, oare, lucrurile stau chiar așa?

Este cunoscut faptul că timpul pe care îl petrece, în prezent, omul contemporan și nu doar tinerii sau ,"nativii digitali” în compania tehnologiei digitale este de 6-9 ore, pe zi. Din acestea, un studiu arată că o persoană petrece, zilnic, 2 ore utilizând telefonul inteligent. Din cele 2 ore, doar o cincime din timp, adică 25 de minute, este dedicată convorbirilor, restul timpului fiind folosit cu scrierea de SMS-uri, conectarea la internet, la rețelele de socializare etc. ${ }^{42}$

Copiii și adolescenții sunt categoria care folosește cel mai intens tehnologia digitală.

La nivel global, dacă în urmă cu cinci ani era normal ca un copil să primească un telefon la 11 ani, acum copii de 4 şi 5 ani au propriile telefoane mobile, simțindu-se mai bine în compania lui, decât în a unei cărți ${ }^{43}$. În România, 53\% dintre copii au primit primul dispozitiv digital la dorința lor, iar 23\% la dorința părinților sau a familiei. $11 \%$ l-au primit pentru a fi în pas cu prietenii sau colegii, iar $12,8 \%$ l-au primit cadou ${ }^{44}$.

De asemenea, studiile arată că o persoană își verifică telefonul, în medie, de 150 de ori în fiecare zi. Presupunând că fiecare accesare a lui ar lua un singur minut, aceasta ar însemna 2,5 ore de distragere, în fiecare zi, adică 912,5 ore pe an, ceea ce echivalează cu 38 de zile în fiecare $\mathrm{an}^{45}$.

Un studiu, efectuat în Marea Britanie, a arătat că $52 \%$ dintre utilizatorii de smartphone (dintre care 62\% cu vârste între 18-30 de ani) folosesc telefonul ca alternativă la a sta și a medita în solitudine. Ca motive ale folosirii lui, 70\% îl folosesc pentru a scăpa de singurătate; $68 \%$, când se plictisesc și au timp de pierdut; $61 \%$, când așteaptă ceva sau pe cineva ${ }^{46}$. Este foarte interesant că, deși este vorba de o cantitate foarte mare de timp, motivul utilizării lui nu

\footnotetext{
${ }^{42}$ J.-C. Larchet, Captivi în internet..., p. 23.

${ }^{43}$ Dr. Elizabeth Kilbey, Creşterea copilului în era digitală. Ghid de parenting responsabil, traducere: Andra-Cristina Nichifor, Editura Niculescu, Bucureşti, 2019, p. 116.

${ }^{44}$ Adina-Brîndușa Baciu, Adicția digitală - boală a societății postmoderne, Editura Pro Universitaria, București, 2019, p. 31.

${ }^{45}$ Amy Blankson, Viitorul fericirii. Cinci strategii moderne de echilibrare a productivității și a stării de bine în era digitală, cuvânt înainte de Schawn Anchor, traducere din limba engleză de Vasile-Radu Filip, Editura Velland, București, 2019, p. 191.

${ }^{46}$ A. Gazzaley, L.D. Rosen, Mintea distrată..., p. 249.
} 
este acela al intensificării relațiilor cu alte persoane, ci al umplerii clipelor "goale", fără ocupație și sens, alungarea singurătății și a tristeții. Am putea spune că este folosit pentru a corecta unele stări disfuncționale psihic, decât în scop creativ și constructive - al consolidării relațiilor interpersonale.

Între efectele negative ale folosirii excesive ale telefonului inteligent, este tot mai larg răspândita „,nomofobie” - teama de a fi lipsit sau privat, chiar și pentru timp scurt, de dispozitivele digitale sau de conexiunea la net. Un sondaj, ce a inclus 3.000 de persoane, a arătat că nouă din zece adulți sub treizeci de ani experiau o teamă intensă, atunci când nu aveau telefonul lângă ei. Acest lucru a fost confirmat și de o altă cercetare, ce a demonstrat că jumătate din persoanele posesoare ale unui smartphone ar simți acut lipsa lui, dacă nu 1-ar avea la îndemână o oră sau chiar mai puțin, iar 55\% dintre femei au spus că ar fi mai dispuse să plece de acasă nemachiate, decât fără telefon ${ }^{47}$.

Dincolo de efectele pozitive ale folosirii dispozitivelor digitale, utilizarea excesivă a telefonului inteligent are efecte negative, clar atestate științific. Folosirea lui înainte de culcare, derularea de imagini variate și de sunete puternice duce la creșterea gradului de excitație fizică și psihică, la întârzierea somnului sau la un somn incomplet și de proastă calitate și, în consecință, la starea de oboseală cronică, la lipsă de performanțe și randament slab, iritare, anxietate și depresie ${ }^{48}$.

Un autor vorbea chiar despre folosirea smartphone-ului, seara, în dormitor și în pat, pe postul de „iPăturică” ${ }^{49}$, de către „tehnopuști $^{50 \prime}$, iar mai târziu de către „digi-prichindei” ${ }^{\prime 51}$.

Adeseori, părinții folosesc telefonul inteligent pe post de „,bonă”, căci, „,ând un copil mic plânge sau este agitat, gălăgios și deranjează pe cei din jur, ce îl liniștește imediat? Un smartphone... Aceasta este o imagine pe care o vedem zilnic. De multe ori chiar suntem inițiatori și participanți la aceasta, noi înșine fiind cei care oferim copiilor telefonul mobil pentru a obține liniștea de moment,

\footnotetext{
${ }^{47}$ Ibidem, pp. $255-256$.

${ }^{48}$ P.M. Valkenburg, J. Taylor Piotrowski, Generația digitală şi dependența de media..., p. 278.

${ }^{49} \mathrm{~J}$. Glod, Părinte în era digitală..., p. 127.

${ }^{50}$ Ibidem, p. 168

${ }^{51}$ Ibidem, p. 168.
} 
atât de mult dorită. Dacă telefonul nu este unul performant, micuțul îl va refuza și crizele de plâns reîncep. Înainte de a le pune la dispoziție copiilor mici un astfel de gadget, ar trebui să ne gândim mai mult și să avem în vedere consecințele nefaste ale utilizării excesive a smartphone-ului de la vârste timpurii. Să încercăm să rezolvăm aceste situații altfel: prin joc, prin îndreptarea atenției spre altceva, prin discuții, prin scurte povestiri, prin stimularea imaginației, chiar dacă toate acestea sunt mult mai solicitante, iar efectul nu este pe măsură. Timpul pe care părintele îl oferă copiilor, pentru a discuta, cu răbdare, problemele importante pentru ei, este unul câștigat și nu un timp irosit. E un timp investit în dezvoltarea armonioasă și sănătoasă a copiilor, în educația lor, în formarea lor ca adulți echilibrați" ${ }^{52}$.

Sau, precum observa un alt analist al acestor realități, „putem vedea la locurile de joacă din ce în ce mai multe mame și mai mulți tați, preocupați mai degrabă de telefonul lor inteligent decât de copiii care se joacă la groapa cu nisip. După cum o arată și cercetările psihologei Melody Bacon, putem fi împreună, fără a vorbi între noi. Cel care discută adesea cu tinerii constată că multora le este din ce în ce mai greu să-1 privească în ochi pe cel cu care vorbește. Preferă să privească ecranul tactil. Când se întâmplă din ce în ce mai frecvent ca abia să vorbim când suntem unul în prezența celuilalt și să nu facem altceva decât să trimitem sms-uri, pentru a evita discuțiile sau din teama de a nu dezvălui prea mult din starea sufletească a fiecăruia, atunci se poate pune sub semnul întrebării sensul faptului că suntem împreună" ${ }^{53}$.

In privința efectelor folosirii abuzive a telefonului inteligent, cercetările ne oferă date și informații interesante. Astfel, studii recente au demonstrat că simpla prezență a unui telefon mobil, chiar și închis, în apropierea noastră, ne scade atenția și productivitatea în sarcinile solicitante cognitiv. Grija de a răspunde prompt la mesaje și apeluri, combinată cu tentația de a face o pauză de concentrare, relaxându-ne, câteva secunde sau minute, navigând pe telefon, spre a afla „noutățile”; multitaskingul, nerăbdarea și superficialitatea afectează puterea de focusare și, implicit, randamentul. De aici și

${ }^{52}$ A.-B. Baciu, Adicția digitală..., p. 100.

${ }^{53}$ Catarina Katzer, Cyberpsihologia. Viața în rețea: Cum ne schimbă Internetul?, traducere din limba germană de Cora Radulian, Editura ALL, București, 2018, p. 273. 
recomandarea specialiștilor: „Ca să te concentrezi asupra muncii tale, mută-ți celularul în afara spațiului vizual (pune-l în geantă, în spatele monitorului computerului sau într-un sertar); dacă acest lucru nu este posibil, cel puțin dezactivează notificările neesențiale. Poți, de asemenea, să-ți iei căști antizgomot, care să te ajute să te concentrezi" ${ }^{54}$.

Un alt experiment, efectuat de profesorul Bill Thorntoin, de la Universitatea Southern Maine (SUA), a demonstrat că simpla prezență a telefonului în apropiere duce la distragerea noastră în faţa sarcinilor complexe, care solicită intens atenția. Același experiment a arătat, în ceea ce privește performanțele studenților, în sala de curs, că prezența telefonului, chiar și pus pe „silence”, afectează negativ atenția celor din jur ${ }^{55}$.

Însă, cercetarea cea mai interesantă pare fi cea făcută în anul 2013, prin care doi psihologi au invitat câte două persoane care nu se cunoșteau, într-un laborator de cercetări, pentru a purta o discuție generală. Bineînțeles, pentru aceasta primeau o sumă modică de bani. Pentru a facilita comunicarea, li s-a sugerat participanților un subiect: să povestească fiecare dintre ei un lucru fericit sau un eveniment interesant, pe care l-au trăit în luna precedentă. Foarte interesant, pe o masă din apropierea unora, la un loc vizibil, psihologii au așezat un smartphone, iar lângă alții, la fel, tot într-un loc vizibil, un caiet. Într-o oarecare măsură, fiecare pereche a creat o anume interacțiune, însă cei aflați în prezența telefonului au realizat acest lucru mult mai greu și superficial, prin mai multe întrebări și afirmații introductive și formale. Toți aceștia au descris comunicarea avută ca fiind de proastă calitate, iar pe partenerii de dialog i-au considerat a fi reci, distanți, lipsiți de empatie și încredere, ba chiar dușmănoși și rău-voitori. Și de această dată, concluzia oamenilor de știință a fost aceea că: „,telefoanele influențează prin simpla lor existență, chiar şi atunci când sunt folosite în mod activ. Ne distrag pentru că ne amintesc de lumea din afara conversației imediate şi singura soluție, conform cercetărilor, este să le eliminăm complet" ${ }^{\prime \prime 5}$.

\footnotetext{
${ }^{54}$ A. Blankson, Viitorul fericirii..., p. 169.

${ }^{55}$ A. Gazzaley, L.D. Rosen, Mintea distrată..., p. 329.

${ }^{56}$ Adam Alter, Irezistibil..., p. 28.
} 
Ori, s-ar părea că pentru mulți tineri, dispozitivul lor este mai important chiar decât relațiile sau prieteniile din lumea reală, odată ce $46 \%$ dintre ei au spus că nu ar putea să trăiască fără telefoanele lor, ba, așa cum am văzut, unii ar prefera să fie ei înşişi răniţi fizic decât să le pățească ceva telefoanele ${ }^{57}$. În absența lui, mulți trăiesc simptomele nomofobiei, teama obsesivă a absenței lui, după numai 10 minute, ceea ce îi face anxioși și depresivi, stare de agitație ce crește proporțional cu durata absenței telefonului lor. Oare același lucru îl pot spune și despre absența părinților ${ }^{58}$ ? Cu excepția familiilor în care unul dintre părinți a părăsit familia, în situațiile în care tinerii au ambii părinți, câți dintre ei și după cât timp de absență a părinților le simt lipsa și le duc dorul?

Tot mai frecvente sunt și crizele, atacurile de furie și de panică, pe care le fac copiii atunci când părinții lor îi pedepsesc, confiscându-le, chiar și pentru un timp limitat, telefonul, tableta sau laptopul, dar și stările de anxietate pe care le simt adulții, atunci când nu au acces la tehnologie și conexiune, chiar și în concediu.

Fetele par a fi mai predispuse decât băieții la dependența de smartphone, iar adolescenții mai mult decât adulții. Dintre factorii de risc, literatura de specialitate menționează: un autocontrol și o stimă de sine scăzute; viețuirea într-o familie disfuncțională, cu părinți severi, violenți sau indiferenți la problemele copiilor; abilități sociale și de inteligență emoțională reduse; eșec școlar și academic; nivel scăzut de conștiinciozitate și nevrotism accentuat; rețea de sprijin redusă; stres cronic, anxietate și depresie; conflicte interioare și interpersonale; impulsivitate ridicată; nivel redus de satisfacție în viață; simptome depresive s. $^{59}$.

Din acest punct de vedere, este mai mult decât îndreptățită observația făcută de Jean-Claude Larchet: „Nu este de mirare că noile media, în calitate de factori de comunicare pe cât se voieşte şi oricând se voieşte, s-au dezvoltat într-o societate ai cărei membri nu mai au atât de multe legături ca în societăţile tradiționale, o societate în care generaţiile sunt în conflict, în care familiile se destramă, căsătoria este în criză şi uniunea familială este instabilă, în care tot mai multe persoane, mai ales în oraşe, dar şi la ţară, trăiesc singure,

${ }^{57}$ Ibidem, p. 40.

${ }^{58}$ A. Gazzaley, L.D. Rosen, Mintea distrată..., p. 208.

${ }^{59}$ A.-B. Baciu, Adicția digitală..., p. 90 
nu doar când ajung la bătrânețe, ci chiar la tinerețe. Este o izolare fizică, dar şi psihologică, intensificată de reducerea reperelor şi a valorilor comune, pe baza cărora, odinioară, uşor se puteau stabili relații profunde. La adolescenți, această izolare este accentuată de neînţelegerile, de conflictul dintre generații, induse de schimbările din societate (atât în privinţa valorilor, cât şi a tehnologiilor), care s-au produs foarte rapid şi la care părinţii nu s-au adaptat la fel de uşor precum copiii. În mod paradoxal, hipercomunicarea nu rezolvă problema singurătăţii, ci într-o anumită măsură o agravează" ${ }^{\prime 60}$.

Adesea, vedem soți și soții, părinți și copii, colegi și prieteni, unul lângă altul, dar fiecare cu ochii ațintiți doar asupra telefonului său, care devine personaj principal, în timp ce prietenul sau prietena, soțul sau soția, colegul sau fratele ocupă un loc secundar în activitatea sa din acel moment, iar mai apoi, în însăși viața lui. Sau, cum constata o autoare: „Fiecare cu ochii în telefonul lui. Atât de aproape şi totuşi atât de departe unul de celălalt!"61. "Împreună, dar alături” sau, precum titlul unei lucrări: „Alone Together" - „Singuri, împreună"'62.

${ }^{60}$ J.-C. Larchet, Captivi în internet..., pp. 119-120.

${ }^{61}$ Dr. Mary Aiken, The Cyber Effect. Psihologia comportamentului uman în mediul online, traducere: Vasile Bontaş, Editura Niculescu, Bucureşti, 2019, p. 17.

${ }^{62}$ Sherry Turkle, Alone Together. Why we expect more from technology and less from each other, Basic Books Printing House, 2017. 